\title{
Global atmospheric responses to Antarctic forcing
}

\author{
David H. Bromwich, ${ }^{1,2}$ Biao Chen, ${ }^{1}$ Keith M. Hines, ${ }^{1}$ Richard I. Cullather ${ }^{1}$ \\ ${ }^{1}$ Polar Meteorology Group, Byrd Polar Research Center, The Ohio State University, Columbus, OH 43210, U.S.A. \\ ${ }^{2}$ Atmospheric Sciences Program, Department of Geography, The Ohio State University, Columbus, OH 43210, U.S.A.
}

\begin{abstract}
To evaluate the greatest impact that sea-ice anomalies around Antarctica could have on the global atmosphere, 15 year seasonal cycle simulations are conducted with the U.S. National Center for Atmospheric Research Community Climate Model version 2.1. Sensitivity simulations are performed with the following conditions: (1) all sea ice in the Southern Hemisphere is replaced by year-round open water, but the permanent ice shelves are retained (NSIS); and (2) all sea ice in the Southern Hemisphere and the major ice shelves are removed and replaced by open water (NISH). The results are compared to a standard run (CNT) with boundary conditions set for the present climate. The comparison shows that trains of positive and negative anomalies in zonal-mean fields extend into the tropical latitudes of the Northern Hemisphere. Anomalies are largest during April-October. The additional removal of the ice shelves in NISH enhances the response, as zonally averaged anomalies are similar in pattern to those in NSIS but are roughly twice as large poleward of $50^{\circ} \mathrm{S}$, and only slightly larger farther north. Anomalies in the eddy fields are found in both hemispheres. In NISH, and to a lesser degree in NSIS, these anomalies appear to be related to a delayed northern advance over China during June of the rain front associated with the summer monsoon. Consequently, precipitation is enhanced in middle and southern China and decreased in northern China. Observational analyses have also found links between Antarctic sea-ice variations and modulations of the East Asian monsoon.
\end{abstract}

\section{INTRODUCTION}

The global climatic roles of high latitudes, particularly those associated with sea-ice variations, are receiving increasing scrutiny (e.g. Gloersen, 1995; Rind and others, 1995; Simmonds and Jacka, 1995; Washington and Meehl, 1996). Although sea-ice thickness can influence atmospheric structure, its concentration (i.e. percent coverage) is more effective in altering the atmospheric circulation via heat fluxes across the surface-atmosphere interface (Andreas and Murphy, 1986). In a set of wintertime simulations evaluating the sensitivity to sea-ice concentration using a general circulation model, Simmonds and Budd (1991; hereafter SB) found large anomalies in surface heat flux locally as the fraction of open water was varied in the sea-ice zone. These resulted in substantial anomalies in atmospheric circulation and precipitation over the high and middle southern latitudes. Furthermore, Mitchell and Senior (1989) noted that the resulting change in surface roughness contributes substantially to the response to the sea-ice removal in this type of simulation.

Numerical studies on the effect of doubled concentrations of atmospheric $\mathrm{CO}_{2}$ indicate that the high-latitude climate is especially sensitive (Mitchell and others, 1990). Thus, improved knowledge of the global role of high-latitude climate and forcing is very important for both contemporary and paleoclimate applications. For this purpose, a companion study details, in a paper submitted to the fournal of Geophysical Research, the global impacts induced by yearround open water adjacent to Antarctica. In contrast to the methodology of SB, our simulations are performed with seasonally varying forcing in the U.S. National Center for Atmospheric Research (NCAR) Community Climate Model version 2.1 (CCM2), which has a standard horizontal resolution of $\mathrm{T} 42\left(2.8^{\circ}\right.$ lat. $\times 2.8^{\circ}$ long.). This is a suitable model for this study, because it adequately captures most climatic features in southern high latitudes even though it has a highly simplistic treatment of sea ice (Hack and others, 1993; Tzeng and others, 1994). Preliminary results of the companion study are given by Bromwich and Chen (1996; hereafter BC). They compared results of a 10 year simulation without Southern Hemisphere ( $\mathrm{SH}$ ) sea ice and ice shelves to a control run that is conducted with the standard parameter settings in CCM2. From this, they observed and documented significant global impacts, in addition to the regional response, from the ice removal. Substantial changes in such fields as temperature, pressure and precipitation were found in both hemispheres. As expected, the largest $\mathrm{SH}$ anomalies occur in winter, when the thermal forcing at the surface is largest. In the Northern Hemisphere (NH), however, the largest anomalies did not occur simultaneously with the largest $\mathrm{SH}$ anomalies. Thus, the seasonal cycle may have an effect on the cross-Equatorial response.

Global and regional impacts on simulated atmospheric circulation induced by removal of Antarctic pack ice and ice shelves, as demonstrated by $\mathrm{BC}$, can be briefly summarized as follows.

(a) The regional atmospheric responses in July to open water adjacent to Antarctica with seasonally varying forcing are similar to those in perpetual July simulations 
(SB) in many ways. As expected, the largest changes are simulated adjacent to the coast.

(b) A train of positive and negative anomalies of the zonal wind speed appears in the troposphere at high and middle latitudes of the SH. Correspondingly, the polarfront jet tends to merge with the subtropical jet in the upper troposphere, and the high-latitude low-level easterlies weaken.

(c) Anomalies of tropical convective precipitation have large-amplitude seasonal variations.

(d) Spin-up processes show that the anomalies excited by removal of Antarctic sea ice and ice shelves can propagate into the $\mathrm{NH}$ in less than 2 months. Wave activity can propagate the effect from the southern high latitudes to the subtropical region. Then significant changes in the mean flow of lower latitudes by eddy-mean-flow interactions (Held and Phillips, 1990) could lead to tropical anomalies of precipitation and diabatic heating. Once the perturbations are excited in the tropics, associated changes in the $\mathrm{NH}$ can be expected according to prior work (e.g. Lau and Nath, 1994).

Comparison and contrast with previous sea-ice sensitivity simulations (e.g. SB) may provide some clues to the explanation for the above effects. On the one hand, the anomaly patterns and magnitudes in the $\mathrm{SH}$ winter in our simulation are similar to those found by SB in perpetual experiments. On the other hand, because most previous sea-ice simulations (including those for the Arctic) were completed for the winter hemisphere, global responses and impacts in the other hemisphere were not as significant as in this seasonally varying experiment. Numerous studies have shown that the global atmospheric circulation is most sensitive to tropical forcing (e.g. Hoskins and Karoly, 1981). Recent studies have also found the El Niño-Southern Oscillation signal in sea ice, precipitation, zonal wind and other fields near and over Antarctica (Gloersen, 1995; Chen and others, 1996; Cullather and others, 1996). Unfortunately, these studies do not reveal whether the high latitudes have significant feedbacks on global climate or merely act as passive receivers of external forcing. This issue can be addressed in studies, including this one, in which polar climate forcing is modified.

For this study, two 15 year sensitivity experiments are performed with NCAR CCM2 and compared with a standard 15 year control simulation with boundary conditions for the modern climate (CNT). The sea-surface temperature distribution is from the standard CCM2 12 month climatology. The simulations evaluate the greatest impact that sea-ice and ice-shelf change near Antarctica could have on the global atmospheric circulation. A unique feature of these ice-sensitivity experiments is the inclusion of the seasonal cycle. In one sensitivity experiment (NSIS), all sea ice in the $\mathrm{SH}$ is removed and replaced with year-round open water at $-1.9^{\circ} \mathrm{C}$. The major ice shelves (Ross and Filchner-Ronne

Fig. 1. July surface sensible heat flux for (a) CNT, (b) the difference between NSIS and CNT, and (c) the difference between NISH and CNT for 90-45 S. Contour interval is $20 \mathrm{Wm}^{-2}$ in (a) and $40 \mathrm{Wm}^{-2}$ in (b) and (c). Hatching in (b) and (c) denotes statistical significance at the 95\% confidence level.
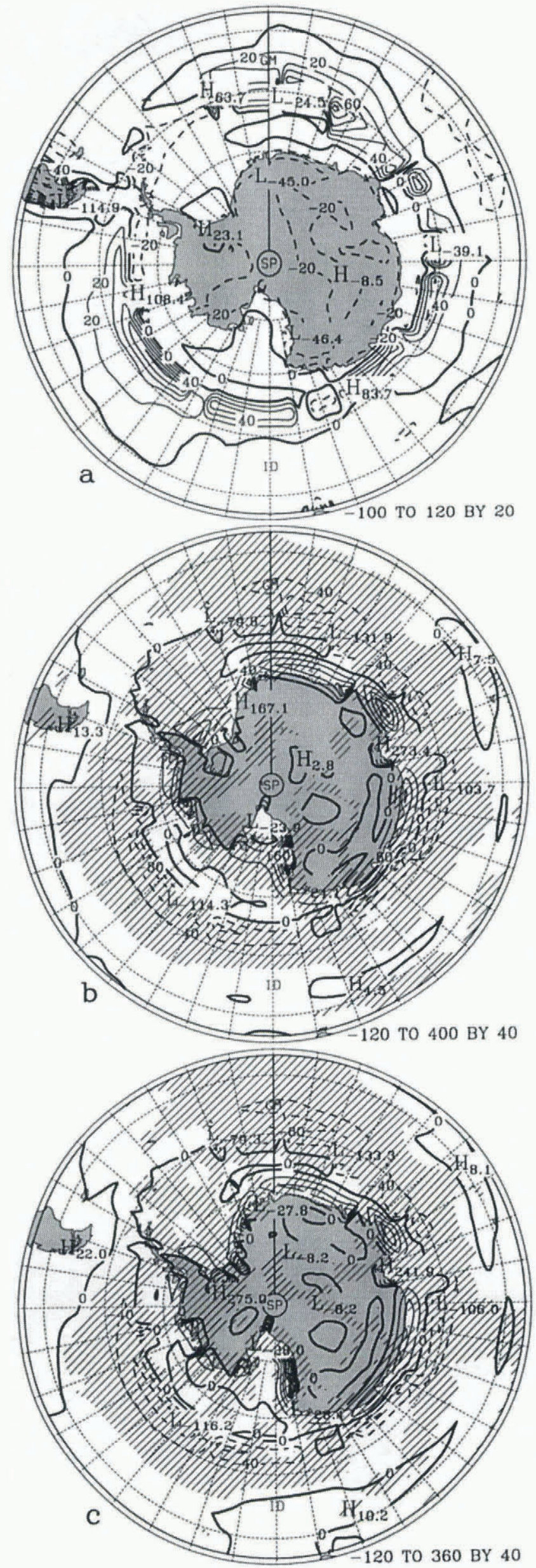
Ice Shelves) are retained. The results of this experiment will be examined in detail in a forthcoming paper. For the present study, the other sensitivity experiment (NISH) is performed with the ice shelves removed in addition to the seaice removal in the $\mathrm{SH}$. We shall focus on the similarities and differences of the responses to the modified forcing in NSIS and NISH. These responses are found to be significant on both hemispheric and global scales. In section 2, the hemispheric impact of the $\mathrm{SH}$ ice removal is examined. The impact in the $\mathrm{NH}$ is considered in section 3. Conclusions are given in section 4.

\section{HEMISPHERIC SENSITIVITY TO SEA-ICE AND ICE-SHELF REMOVAL}

In this section, the austral winter results of the 15 year simulations, NSIS, NISH and CNT, are analyzed and compared in order to gauge the relative sensitivities of $\mathrm{SH}$ climate to removal of sea ice and ice shelves around Antarctica near the time of maximum effect (BC). Figure 1 shows the surface sensible heat flux in CNT and its anomalies in NSIS and NISH over the high southern latitudes during July. Hatching indicates statistically significant anomalies at the $95 \%$ confidence level according to Student's $t$ test. The sea-ice region is the band of relatively low-magnitude heat flux surrounding Antarctica in Figure la. Large differences between Figure $1 \mathrm{~b}$ and $\mathrm{c}$ near $170^{\circ} \mathrm{W}$ and $45^{\circ} \mathrm{W}$ help indicate the location of the permanent ice shelves. In the CCM2 simulation for the present climate, CNT, the maximum sensible heat fluxes (Fig. la) are found over open water to the north of the sea-ice zone with values of up to $133 \mathrm{~W} \mathrm{~m}^{-2}$ during July; this arises in CNT because sea ice is specified to be $2 \mathrm{~m}$ thick and to have a concentration of $100 \%$ (Hack and others, 1993; Tzeng and others, 1994). In NSIS and $\mathrm{NISH}$, surface temperatures are as much as $35 \mathrm{~K}$ warmer than in CNT. The direct local impact of removal of sea ice on the surface heat flux (Fig. lb) indicates that in the sea-ice region the anomalous sensible heat fluxes are positive (upward) everywhere, with values often exceeding $100 \mathrm{~W} \mathrm{~m}^{-2}$ and an extreme value of $406 \mathrm{~W} \mathrm{~m}^{-2}$ in the western Ross Sea. There are negative anomalies in areas just to the north of the sea-ice edge. This result is generally consistent with the findings in $\mathrm{SB}$ except that the maximum values are about $25 \mathrm{~W} \mathrm{~m}^{-2}$ larger; this may primarily be caused by the inclusion of seasonal variations in this experiment, in addition to different depictions of sea-surface temperatures. The positive sensible heat flux anomalies arise because lowlevel air from Antarctica gains more sensible heat as it blows over the open water in NSIS than it would over the $2 \mathrm{~m}$ thick sea-ice cover in CNT (SB).

Removal of the ice shelves (Fig. 1c) leads to maxima in sensible heat flux anomalies that are closer to West Antarctica. Nevertheless, the patterns, including negative anomalies to the north of the sea-ice zone, are very similar in Figure $1 \mathrm{~b}$ and $\mathrm{c}$, as the area of the ice shelves is an order of magnitude smaller than that of sea ice. There are two positive-anomaly maxima, located along the edge of the Ronne Ice Shelf at $79.53^{\circ} \mathrm{S}$ and along the Amundsen Sea coast of the Ross Ice Shelf at $85.10^{\circ} \mathrm{S}, 274$ and $364 \mathrm{~W} \mathrm{~m}^{-2}$, respectively. One important aspect of NISH is that the shelf removal allows maxima of sensible heat fluxes to be closer to the South Pole. The latent-heat flux anomalies (not shown)
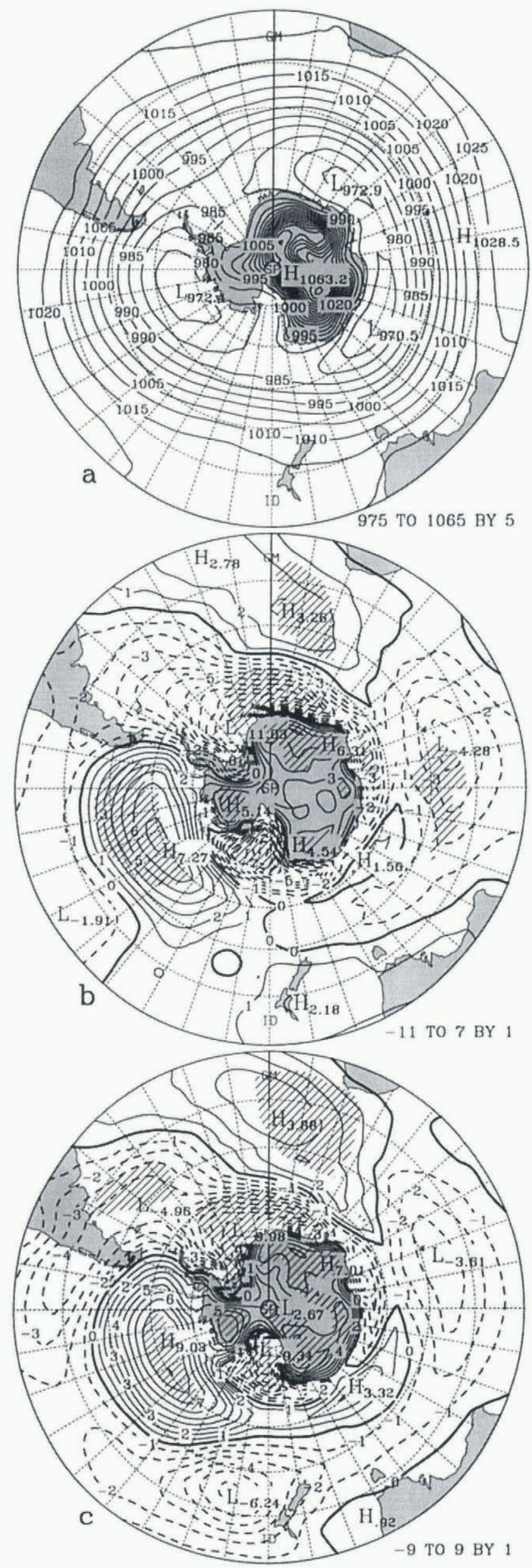

Fig. 2. July sea-level pressure for (a) CNT, and the difference in surface pressure (b) between NSIS and CNT, and (c) between NISH and CNT for $90-30^{\circ} \mathrm{S}$. Contour interval is $5 \mathrm{hPa}$ in $(\mathrm{a})$ and $1 \mathrm{hPa}$ in $(\mathrm{b})$ and $(\mathrm{c})$. 
in the experiments have a similar structure, but the magnitudes are typically one-third of those for sensible heat.

Simulated sea-level pressure around Antarctica for CNT is shown in Figure 2a. Minima in pressure tend to migrate toward maxima in sensible heat flux. Therefore, the circumpolar trough is about $3-5^{\circ}$ closer to Antarctica and slightly strengthened in NSIS compared with CNT in response to the anomalous increased heat flux near the coast (Fig. 2b). Curiously, the circumpolar trough, though located more to the south, is not more clearly strengthened in NISH than in CNT (Fig. 2c). The Amundsen Sea low near $95^{\circ} \mathrm{W}$ in the sea-level pressure field displayed in Figure 2a moves westward to near $160^{\circ} \mathrm{W}$ in the Ross Sea in NSIS and NISH (not shown), and the two low centers over the Indian Ocean tend to merge and become less distinct, apparently due to the heat flux maximum near the Amery Ice Shelf. Surface pressure anomalies in Figure $2 b$ and $c$ indicate that significant reductions occur in coastal regions previously occupied by sea ice, except for the increase west of the Antarctic Peninsula. The anomaly patterns are quite similar, except for a slightly larger reduction in pressure in NISH where the Ross Ice Shelf was removed. At $80^{\circ} \mathrm{S}$, $177^{\circ} \mathrm{W}$, the pressure anomaly is $-7.8 \mathrm{hPa}$ in NSIS and $-9.1 \mathrm{hPa}$ in NISH. An especially large and significant pressure increase is located near $60^{\circ} \mathrm{S}, 110^{\circ} \mathrm{W}$. The pressure anomalies to the north of the former sea-ice edge display a wavenumber 2-3 pattern, which may reflect the asymmetry of the forcing associated with sea-ice and ice-shelf removal. This observation is supported by the NISH anomalies essentially having a more noticeable wavenumber 2 pattern in response to enhancement of the heat-flux anomalies via removal of the two ice shelves near West Antarctica. The pattern and magnitude of the anomalies in sea-level pressure are similar to those obtained by SB.

Figure 3 displays a zonally averaged cross-section of the zonal wind component averaged over the months June, July and August. A significant train of positive and negative anomalies appears in the middle-upper troposphere of the southern high and middle latitudes, with a magnitude of about $1-2 \mathrm{~m} \mathrm{~s}^{-1}$ in NSIS (Fig. 3b) and a somewhat larger magnitude in NISH (Fig. 3c). These indicate weakened westerlies between $50^{\circ}$ and $75^{\circ} \mathrm{S}$, and decreased polar lowlevel easterlies. The former is consistent with a weakened horizontal temperature gradient over the former sea-ice region. The coastal warming associated with the sea-ice removal has also increased the temperature gradient over Antarctica, resulting in higher tropospheric wind speeds near the South Pole. The westerly anomaly at $40^{\circ} \mathrm{S}$ results in the polar-front jet merging with the subtropical jet in the upper troposphere for NSIS (not shown). The tropical easterlies are also reduced throughout the atmosphere. Zonally averaged anomalies in the $\mathrm{NH}$ display a much weaker response. This is also true in the northern winter (DJF; not shown). The anomalies in NISH south of $50^{\circ} \mathrm{S}$ are approximately twice as large as those in NSIS, while the responses are about the same magnitude elsewhere in the SH. The doubling of the high southern latitude response cannot be explained simply by the ratio of the much smaller surface area of the ice shelves to that of winter SH sea ice. This would suggest that the location of the surface-forcing change, not just the area of the affected surface, is vital to the response.

The meridional mass flux (Wu and Brankovic, 1985), a scalar quantity related to the zonally averaged circulation
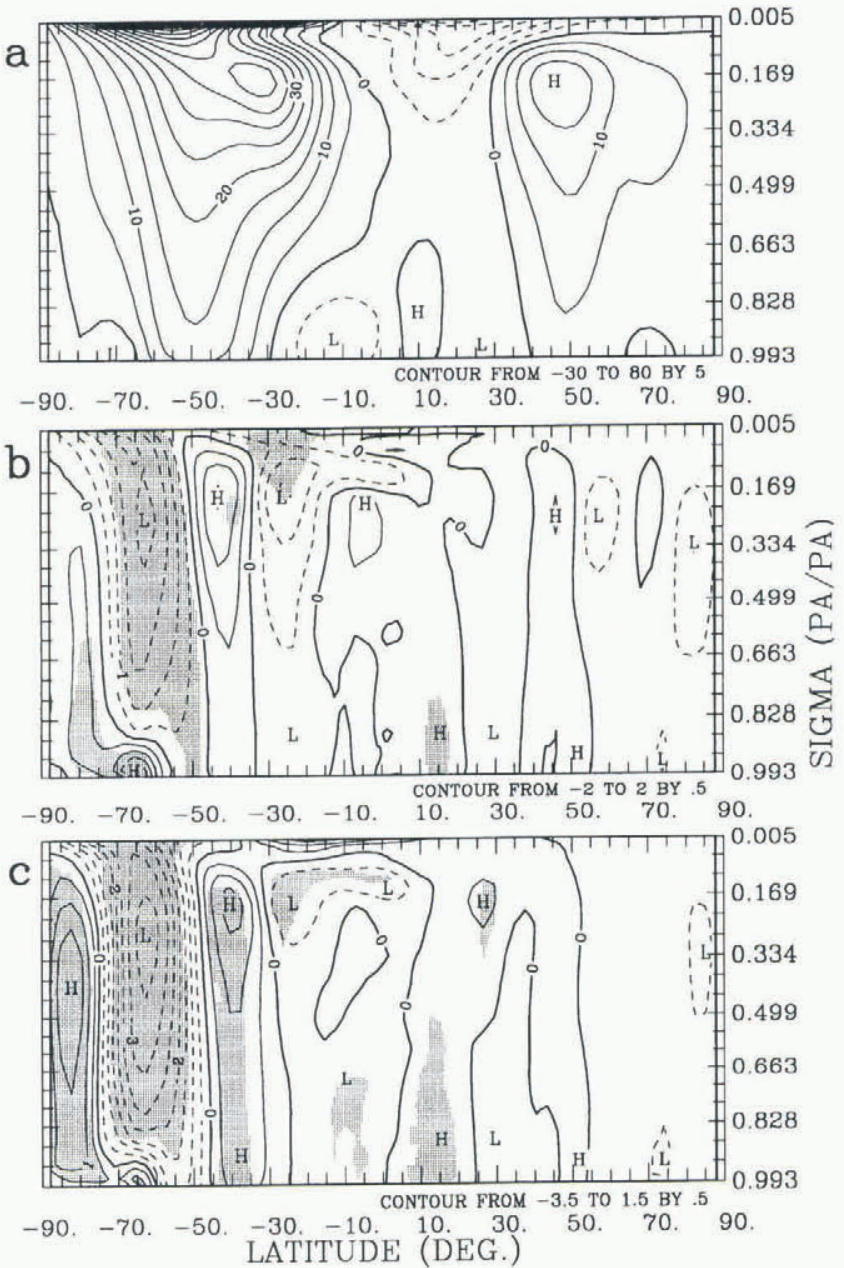

Fig. 3. Zonally averaged vertical cross-section of zonal wind averaged for fune, fuly and August for (a) CNT, (b) the difference between NSIS and CNT, and (c) the difference between NISH and CNT. Contour interval is $5 \mathrm{~m} \mathrm{~s}^{-1}$ in (a) and $0.5 \mathrm{~m} \mathrm{~s}^{-1}$ in (b) and (c).

in the latitude-pressure plane, is shown in Figure 4. The circulation is parallel to the contours, and the speed is inversely proportional to contour spacing in Figure 4. Positive (negative) areas of meridional mass flux indicate clockwise (counterclockwise) circulation. In Figure 4a for CNT, the direct meridional circulation cells for the polar and tropical regions of the $\mathrm{SH}$ and the indirect Ferrel cell between them are clearly visible. In contrast, the summertime circulation in the NH is very weak. The anomaly fields in Figure $4 \mathrm{~b}$ and c indicate that the sea-ice removal modulates the meridional circulation in the $\mathrm{SH}$ by roughly $10 \%$. Statistically significant positive anomalies in latent heating (not shown) accompany the upward-directed anomalies near $10^{\circ} \mathrm{N}$ and $45^{\circ}$ and $70^{\circ} \mathrm{S}$. With the removal of the ice shelves in NISH, a stronger response is seen in Figure $4 c$ than in $b$. The polar direct cell is enhanced south of $70^{\circ} \mathrm{S}$ in both sensitivity experiments; this anomaly is about $50 \%$ larger in NISH than in NSIS. This difference can be related to the much larger latent heating in the lower troposphere south of $80^{\circ} \mathrm{S}$ in NISH than in NSIS. This emphasizes the impact of the southerly location of the relatively warm open water where the ice shelves are removed. Furthermore, the increased zonal velocity component over Antarctica (Fig. 3b and c) can be explained by Coriolis turning of the anomalous poleward motion in the middle and upper troposphere. The decreased zonal velocity component between $70^{\circ}$ and $50^{\circ} \mathrm{S}$ 

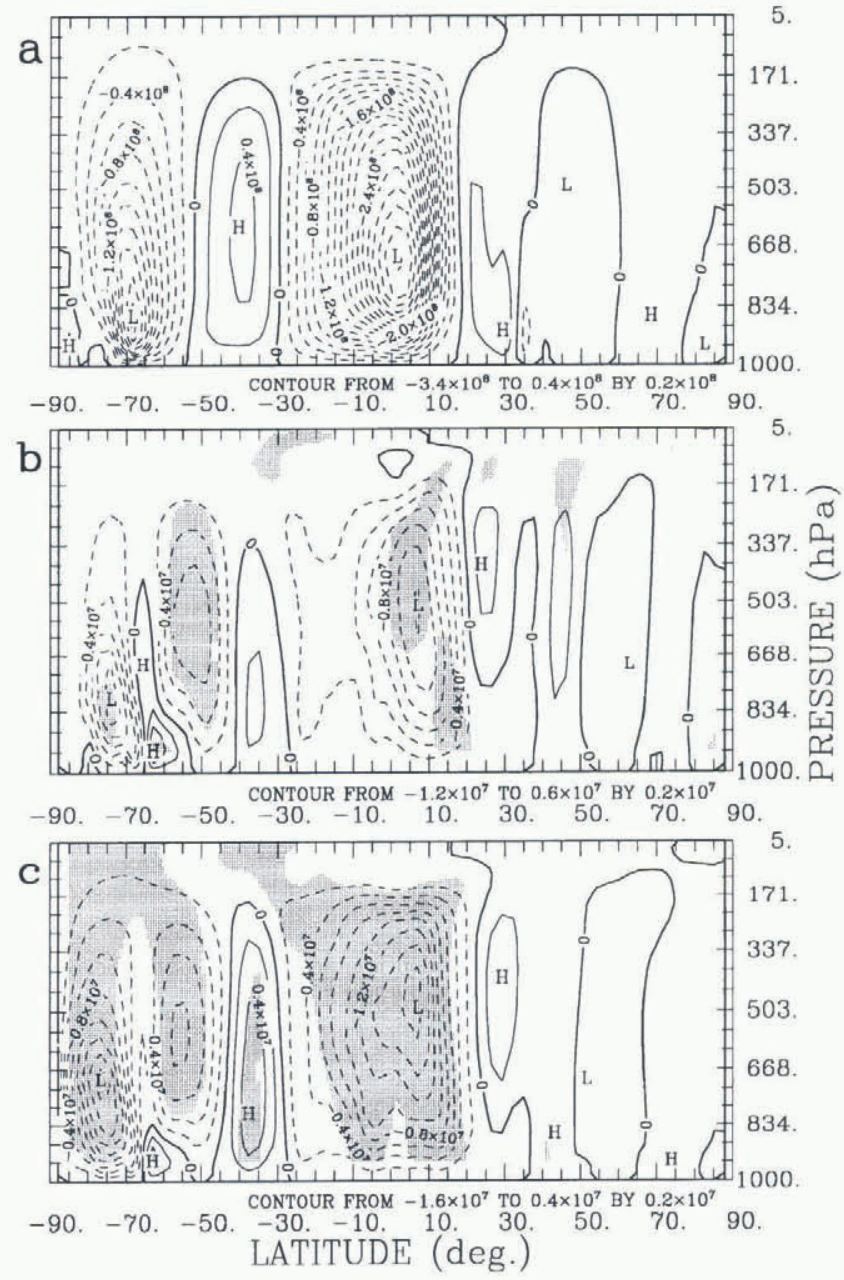

Fig. 4. Same as Figure 3 except for the meridional mass flux. Contour interval is $0.2 \times 10^{8}$ ton $^{-1}$ in $(a)$ and $0.2 \times 10^{7}$ ton $s^{-1}$ in $(b)$ and $(c)$.

cannot be explained simply by Coriolis turning, indicating that eddy fluxes are important here. Another important feature displayed in Figure $4 \mathrm{~b}$ and $\mathrm{c}$ is that statistically significant modifications to the atmospheric circulation extend into tropical regions of the $\mathrm{NH}$.

\section{NH IMPACTS OF SH SEA-ICE REMOVAL}

Several paleoclimate studies suggest that interhemispheric interaction through the atmosphere (Kerr, 1996) may exist despite the lack of detailed observational and theoretical support. Available theory includes Held and Hoskins' (1985) discussion of "wave stress" to illustrate how extratropical Rossby waves radiate to the tropics, decelerate the subtropical jet and influence the location and intensity of the Hadley circulation. Once tropical disturbances in precipitation and latent heat are excited, Rossby waves would be emitted to the northern middle and high latitudes and could alter the mean meridional circulation as numerous studies have suggested (Hoskins and Karoly, 1981; Yang and Webster, 1990).

Analysis of various zonal mean fields in the NH (not shown) indicates that the anomalies resulting from the seaice removal are generally small. Nevertheless, significant anomalies are found in the eddy fields of the NH. The summer monsoon rains over China, which are known to have a large and important climate variability (Domrös and Peng, 1988), are found to be highly sensitive to our seaice removal experiments. A large impact of the sea-ice removal in the NSIS simulation was found in September, about the time of transition from warm, moist southerly winds to much cooler, drier northerly winds of the winter monsoon (Domrös and Peng, 1988). This finding will be detailed in a forthcoming publication. Here, we discuss results during June, when the monsoon "rain front" typically moves northward.

Figure 5 shows a regional precipitation field for CNT, and the difference fields between NSIS and CNT and between NISH and CNT. June precipitation is $20-35 \mathrm{~cm}$ over much of northern and central China in CNT. Values tend to be too large because of CCM2 errors, particularly inland where "locking" of precipitation over steep topographic features occurs (Hack and others, 1994). Observations of the climatological June precipitation in this region are typically $6-20 \mathrm{~cm}$, with a general decrease to the north (Domrös and Peng, 1988). The difference field in Figure 5c shows that June precipitation is enhanced in
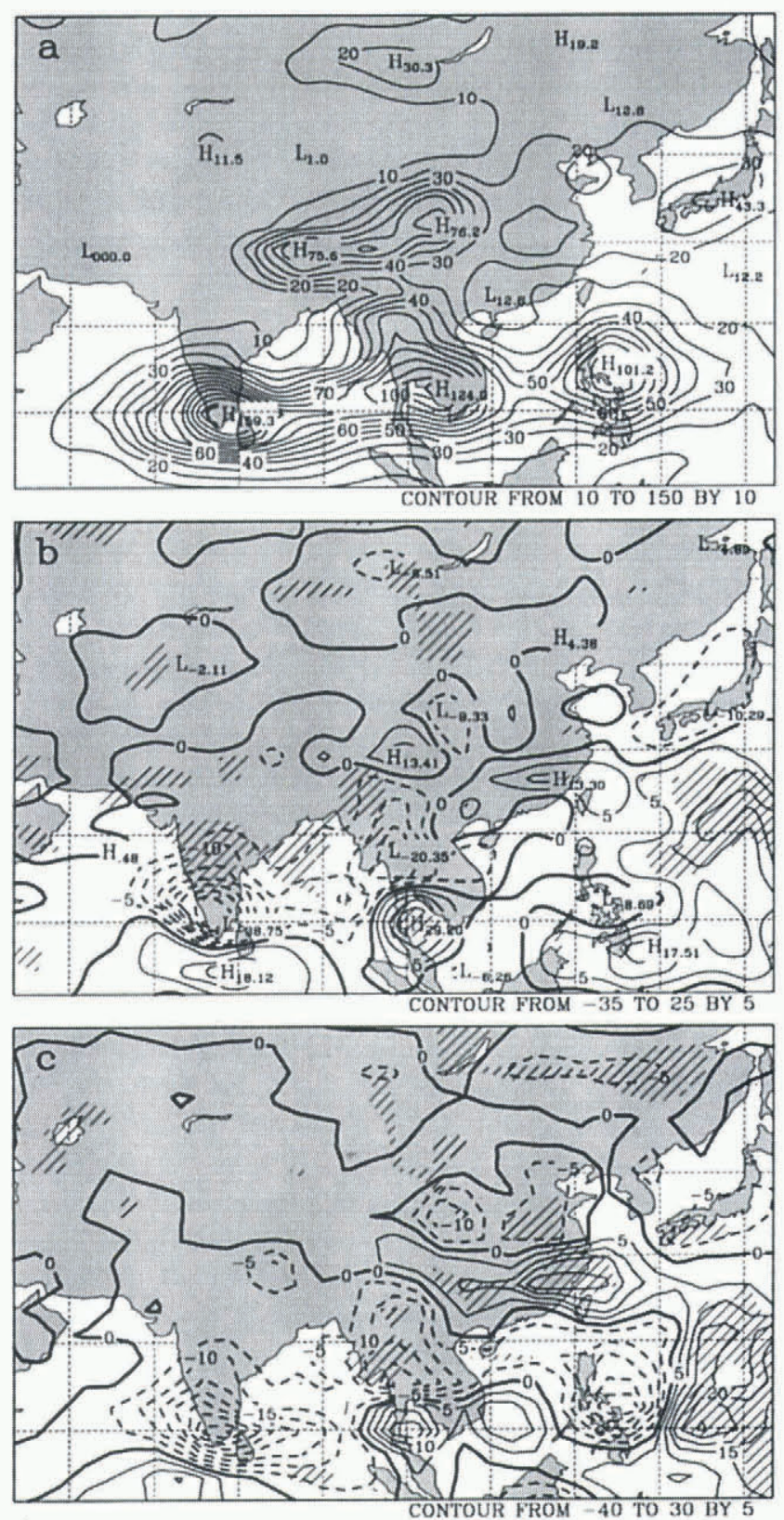

Fig. 5. Regional plot of June precipitation for ( a ) CNT, (b) the difference between NSIS and CNT, and (c) the difference between NISH and CNT. Contour interval is $10 \mathrm{~cm}$ in (a) and $5 \mathrm{~cm}$ in $(b)$ and $(c)$. 
central and southern China by as much as $24 \mathrm{~cm}$ in NISH. Over northeastern China, precipitation is decreased by as much as $7 \mathrm{~cm}$. Both the increase and decrease are statistically significant. Thus, the monsoon rain front is located more to the south in response to the sea-ice and ice-shelf removal. This surprising result bears similarity to that of a previous observational study. Correlations between Antarctic sea-ice extent and northern China river runoff were found by Peng and Domrös (1987). They found sensitivity to be particularly large for sea ice between $150^{\circ} \mathrm{W}$ and $180^{\circ}$, about the longitudes of the eastern two-thirds of the Ross Ice Shelf. They also noted the meteorologically consistent links between variations of precipitation, the East Asian summer monsoon and the subtropical western Pacific high. Furthermore, they correlated the intensity and location of the high to the extent and distribution of Antarctic sea ice.

The pattern in Figure 5b suggests a similar precipitation change over China in NSIS. The magnitude of the anomaly, however, is smaller; its statistical significance is not well confirmed at the $95 \%$ confidence level. Other anomalies in precipitation appear roughly similar in magnitude and location for the difference fields in Figure $5 \mathrm{~b}$ and $\mathrm{c}$. The eddy anomalies in other meteorological fields in the $\mathrm{NH}$ also show similarity between NSIS and NISH. A consistent pattern of stronger eddy anomalies for either NSIS or NISH is not found in the NH. Thus, the amplified response to the ice-shelf removal in NISH is largely confined to the SH, especially high southern latitudes.

Precipitation anomalies over China in Figure $5 \mathrm{c}$ are consistent with the response of the pressure field to the Antarctic sea-ice and ice-shelf removal in NISH (Fig. 6). Surface geostrophic flow over China is basically south-southwesterly and contributes to the northerly position of the monsoon rain front in CNT (Fig. 6a). The surface pressure anomaly for NISH in Figure 6b opposes low-level southerly flow over China, as there is increased pressure near $50^{\circ} \mathrm{N}, 125^{\circ} \mathrm{E}$ and decreased pressure near $23^{\circ} \mathrm{N}, 140^{\circ} \mathrm{E}$. Both of these anomalies are larger than $2.5 \mathrm{hPa}$ in magnitude and highly statistically significant. Therefore, the southward displacement of the rain front in NISH does not appear to be the result of CCM2 precipitation errors, but seems rather to be due to a significant modification of the summer monsoon circulation. The mechanism resulting in the precipitation and pressure anomalies, although not known for certain, can be hypothesized from the pressure anomalies in Figure $6 \mathrm{~b}$ and the meridional circulation anomalies in Figure 4c. During June, a train of four pressure anomalies extends northward from $54^{\circ} \mathrm{S}, 155^{\circ} \mathrm{E}$ to the western North Pacific Basin. The negative anomaly at $54^{\circ} \mathrm{S}, 155^{\circ} \mathrm{E}$, despite large magnitude $(6 \mathrm{hPa})$, is not statistically significant as it is located in a band of large pressure variance. The three anomalies to the north, however, are statistically significant. The negative pressure anomalies near $54^{\circ} \mathrm{S}$ and $23^{\circ} \mathrm{N}$ roughly correspond to the latitudes of anomalous zonally averaged ascent during June, July and August implied by Figure 4c. Similarly, the positive pressure anomaly over Australia is near latitudes of anomalous descent. From these considerations, we may reasonably suggest that a wave train extends northward from high southern latitudes and influences the monsoon. The modulation of the monsoon occurs during the time of year when the sea ice is fairly extensive and the temperature contrast between Antarctica and open water is high. The unique forcing in NISH includes relatively warm open water in the western South Pacific where the Ross Ice org/10.3189/1998AoG27-1-521-527 Published online by Cambridge University Press
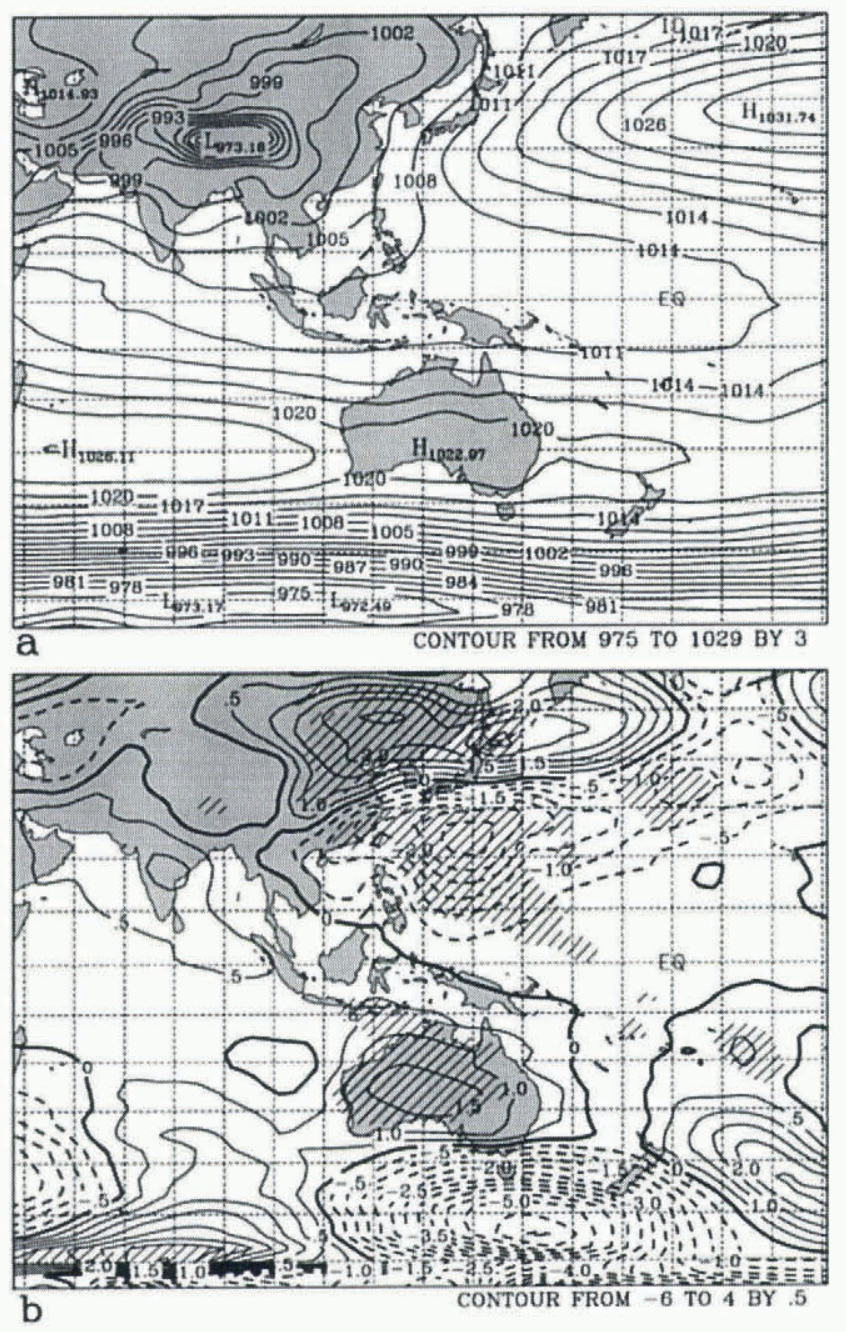

Fig. 6. Same as Figure 5 except for (a) sea-level pressure and (b) the difference in surface pressure between NISH and $C N T$. Contour interval is $3 \mathrm{hPa}$ in ( $a$ ) and $0.5 \mathrm{hPa}$ in $(b)$.

Shelf is located in CNT. The finding that ice removal in NSIS and NISH can be related to modifications in the East Asian monsoon and precipitation is of key importance, in that it relates the results of our extreme experiments, in which all Antarctic sea ice was removed, to observed variations in the modern climate. Significant, non-local variability in climate may thus be associated with realistic changes in Antarctic sea ice.

\section{CONCLUSIONS}

The maximum impacts of sea ice and ice shelves on regional and global climate have been reviewed and examined in a set of sensitivity experiments with CGM2 that include seasonal cycles. Similarities and differences in the responses to the modified forcing are noted in the following simulations: (1) sea ice in the $\mathrm{SH}$ is replaced by year-round open water at $-1.9^{\circ} \mathrm{C}$ (NSIS), and (2) sea ice and ice shelves in the $\mathrm{SH}$ are replaced by open water (NISH). Responses in the $\mathrm{SH}$ are largest during the austral winter. The mean meridional circulation in the $\mathrm{SH}$ is modulated by roughly $10 \%$ due to the sea-ice removal. If the ice shelves are removed in addition to sea ice around Antarctica, maximum anomalies of sensible heat flux move closer to the South Pole. This apparently results in zonal wind anomalies in NISH about twice as large as those in NSIS south of $50^{\circ} \mathrm{S}$, even though the sur- 
face area of winter sea ice is an order of magnitude larger than that of the ice shelves. The surface pressure anomalies show the dominance of wavenumber 2 in NISH, while a mixed wavenumber 2 and 3 pattern prevails in NSIS, apparently related to the geographic location of the two large ice shelves near West Antarctica.

Interhemispheric responses are also noted in the eddy fields of NSIS and NISH. In the latter simulation, the northward movement of the summer monsoon rain front appears to be delayed over China during June. Thus, precipitation is increased in southern and central China and decreased in northern China in response to the Antarctic ice removal. This surprising finding is supported by the observational study of Peng and Domrös (1987). They correlated Antarctic sea-ice extent with river runoff in northern China and variations in the subtropical western Pacific high. Thus the results of our extreme sea-ice removal experiments can be related to observed variations in the modern climate. Possible mechanisms for global propagation of the impact of the Southern Ocean surface heating anomaly will be discussed in a forthcoming paper.

\section{ACKNOWLEDGEMENTS}

The work was supported by NASA grant NAGW-2718. The computations were mainly performed on the CRAY Y-MP of the Ohio Supercomputer Center; we thank C. Bender for the grant of substantial computer time from the Director's Discretionary Fund. This paper is contribution No. 1063 of the Byrd Polar Research Center.

\section{REFERENCES}

Andreas, E. L. and B. Murphy. 1986. Bulk transfer coefficients for heat and momentum over leads and polynyas. f. Phys. Oceanogr., 16 (11), 1875-1883. Bromwich, D. H. and B. Chen. 1996. Global atmospheric impacts induced by sea ice anomalies around Antarctica. In Eighth Conference on Air-Sea Interaction and Conference on the Global Ocean-Atmosphere-Land System (GOALS), Atlanta, Georgia. Proceedings. Boston, MA, American Meteorological Society, 218-222.

Chen, B., S. R. Smith and D. H. Bromwich. 1996. Evolution of the tropospheric split jet over the South Pacific Ocean during the 1986-1989 ENSO cycle. Mon. Weather Rev., 124(8), 1711-1731.

Cullather, R. I., D. H. Bromwich and M. L. van Woert. 1996. Interannual variations in Antarctic precipitation related to El-Niño-Southern Oscillation. 7. Geophys. Res, 101 (D14), 19,109-19,118.
Domrös, M. and Peng Gongbin. 1988. The climate of China. New York, Springer-Verlag.

Gloersen, P. 1995. Modulation of hemispheric sea-ice cover by ENSO events. Nature, $373(6514), 503-506$.

Hack, J. J., B. A. Boville, B. P. Briegleb, J.T. Kiehl, P.J. Rasch and D. L. Williamson. 1993. Description of the NCAR Community Climate Model (CCM2). Boulder, CO, National Center for Atmospheric Research. (NCAR Technical Note TN-382+STR.)

Hack, J. J., B. A. Boville, J. T. Kiehl, P. J. Rasch and D. L. Williamson. 1994. Climate statistics from the National Center for Atmospheric Research community climate model CCM2. J. Geophys. Res., 99(D10), 20,78520,813 .

Held, I. M. and B.J. Hoskins. 1985. Large-scale eddies and the general circulation of the troposphere. Adv. Geophys., 28, 3-31.

Held, I. M. and B. J. Phillips. 1990. A barotropic model of the interaction between the Hadley cell and a Rossby wave. 7. Atmos. Sci., 47 (7), 850-869.

Hoskins, B. J. and D. J. Karoly. 1981. The steady linear response of a spherical atmosphere to thermal and orographic forcing. 7. Atmos. Sci., 38 (14), 2150-2163.

Kerr, R. A. 1996. Ice bubbles confirm big chill. Science, 272 (5268), 1584-1585.

Lau, N.-C. and M. J. Nath. 1994. A modeling study of the relative roles of tropical and extratropical SST anomalies in the variability of the global atmosphere-ocean system. 7. Climate, 7(8), 1184-1207.

Mitchell, J. F. B. and C. A. Senior. 1989. The Antarctic winter; simulations with climatological and reduced sea-ice extents. Q. J. R. Meteorol. Soc., $\mathbf{1 1 5}(486), 225-246$

Mitchell, J. F. B., S. Manabe, V. Meleshko and T. Tokioka. 1990. Equilibrium climate change - and its implications for the future. In Houghton, J.T., G. J. Jenkins and J.J. Ephraums, eds. Climate change: the IPCC scientific assessment. Cambridge, etc., Cambridge University Press, 131-172.

Peng Gongbin and M. Domrös. 1987. Connections of the West Pacific Subtropical High and some hydroclimatic regimes in China with Antarctic ice-snow indices. Meteorol. Atmos. Phys., 37 (2), 61-71.

Rind, D., R. Healy, C. Parkinson and D. Martinson. 1995. The role of sea ice in $2 \times \mathrm{CO}_{2}$ climate model sensitivity. Part I: The total influence of seaice thickness and extent. F. Climate, 8 (3), 449-463.

Simmonds, I. and W. F. Budd. 1991. Sensitivity of the Southern Hemisphere circulation to leads in the Antarctic pack ice. Q. J. R. Meteorol. Soc., $117(501), 1003-1024$.

Simmonds, I. and T. H. Jacka. 1995. Relationships between the interannual variability of Antarctic sea ice and the Southern Oscillation. 7. Climate, 8(3), 637-647.

Tzeng, R.-Y., D. H. Bromwich, T. R. Parish and B. Chen. 1994. NCAR CCM2 simulation of the modern Antarctic climate. 7. Geophys. Res., 99(D11), 23,131-23,148.

Washington, W. M. and G. A. Meehl. 1996. High-latitude climate change in a global coupled ocean-atmosphere sea-ice model with increasing atmospheric $\mathrm{CO}_{2}$. F. Geophys. Res., 101 (D8), 12,795-12,802.

Wu, G. and C. Brankovic. 1985. General circulation diagnostics package. Reading, European Centre for Medium-Range Weather Forecasts. Research Department. (ECMWF Technical Memo 96.)

Yang, S. and P. J. Webster. 1990. The effect of summer tropical heating on the location and intensity of the extratropical westerly jet streams. F. Geophys. Res., 95 (11), 18,705-18,721. 